\title{
Gastronomi Turizmi Kapsamında Yöresel Yemeklerin Restoranlarda Sunulması Üzerine Bir Araştırma: Şarköy Örneği
}

\section{A Research on the Presentation of Local Foods in Restaurants within the Scope of Gastronomy Tourism: The Case of Şarköy}

\author{
Dr. Öğr. Üyesi Özgür KIZILDEMiR \\ İstanbul Gelişim Üniversitesi \\ Uygulamalı Bilimler Yüksek Okulu, \\ İstanbul,Türkiye \\ E-posta: o.kizildemir@gmail.com
}

\author{
Enver ŞiMŞEK \\ İskenderun Teknik Üniversitesi \\ Sosyal Bilimler Enstitüsü, \\ Hatay, Türkiye
}

E-posta: enversimsek.sbe@gmail.com

Öz

Bu çalışmanın amacı, Tekirdağ'a bağlı Şarköy yöresinde bulunan restoranların, bölgeye ait yöresel yemeklerinin menülerinde yer alma durumunu tespit edip, gastronomi turizmi çerçevesinde değerlendirmektir. Amaca ulaşabilmek adına alan yazın incelenmiş, nitel araştırma yöntemlerinden yarı yapılandırılmış görüşme tekniği ile Şarköy yöresindeki 8 restoran yetkilisinden veriler toplanmıştır. Yerel halkın yemek türlerinde zeytinyağı ve tahıl ürünlerini sıklıkla kullandıkları anlaşılmıştır. Mülakatlar sonucunda, Şarköy'ün yöresel yemeklerinin çok fazla uğraş gerektiren yemekler olması sebebiyle restoranlarda yeterli düzeyde sunulmadığı, diğer sebebin ise talep düşüklüğü olduğu saptanmıştır. Katıımcılar, yöresel yemeklerin tanıtımı için belediye reklam desteklerinin sağlanması, Şarköy yöresinin genel tanıımının yapılması, gastronomi festivalleri yapılması ve festivallere katıım sağlanması gerektiğini belirtmişlerdir.

Anahtar Kelimeler: Restoran, Şarköy, Yöresel Yemek, Gastronomi

\section{Abstract}

The main purpose of this study is to determine the status of restaurants located in the region of Şarköy in Tekirdağ in the menus of the regional dishes of the region and to evaluate them within the framework of gastronomic tourism. In order to reach the goal, the literature was examined, and data was collected from 8 restaurant officials in the region of Şarköy, using the semistructured interview technique, which is one of the qualitative research methods. It is understood that local people frequently use olive oil and cereal products in their food types. As a result of the interviews, it was determined that the local dishes of Şarköy are not served at the restaurants at a sufficient level because of the dishes that require a lot of effort, and the other reason is the low demand. Participants stated that it is necessary to provide municipal advertisement supports for the promotion of local dishes, general promotion of Şarköy region, gastronomy festivals and participation in festivals.

Key Words: Restaurant, Şarköy, Local Food, Gastronomy 


\section{Extended Abstract}

\section{Introduction}

The tourist who visits the region to learn about the culture of the region, tastes the food and beverages of the region and highlights different areas within the phenomenon of tourism and thus the economy of the region has developed (Şen and Silahşör, 2018). With the developing economy, local people and businesses in the region may want to increase the quality in order to meet the demand of the tourist. Bertella (2011) stated that businesses within the scope of gastronomy tourism can encourage senses suitable for all tastes. Also stated that regional food and beverages have a cultural value, and he saw the food culture as a form of expression of the region. At the same time, Yüncü (2009) stated that the food and beverages specific to the region are a distinctive element for the region, and that today's people eat out not only for the purpose of feeding, but also with the desire to experience different tasting experiences.

Turkish, French and Chinese cuisine groups are seen as the most diverse cuisines in the world by experts in gastronomy (Yergaliyeva, 2011). Şarköy stands out as a small settlement close to Istanbul by the sea, with its unique, various agricultural products (Kiper, et al., 2011). For this reason, it is seen that agricultural products are frequently used in meals. With its unique flavors, Şarköy can find an important place in terms of sustainable gastronomy. In his study, Kılıçhan (2015) stated that each foodbeverage, which has its own taste and is ecologically sustainable, is a work of skill, intelligence and creativity that has been formed over the centuries.

When the literature is examined, it has been determined that there are similar studies, but there are not many studies on the Şarköy region, which is a touristic holiday center close to Istanbul. The concept of gastronomy tourism was explained in this study in which the level of serving local foods and beverages in restaurants in the region was explained, and the local food culture and Şarköy food culture were mentioned. In this direction, a meeting was held with restaurant managers in the Şarköy region. It is thought that the results of the study will make a significant contribution to the literature and will be a valuable guide for restaurant authorities.

\section{Method}

The main purpose of this study is to determine the status of the restaurants in the Şarköy region of Tekirdağ to be included in the menus of the local dishes of the region and to evaluate it within the framework of gastronomy tourism. Qualitative research method was used in this study. Within the scope of the research, there are 22 restaurant establishments in the region. The data were collected using semi-structured interview technique from 8 restaurants in the region that accepted the interviews. Semi-structured interview form was used as data collection tool in the study. In the semi-structured interview, 7 main questions are guided and different questions can be asked in accordance with the purpose of the study. In preparing the interview form, Aslan, et al. (2014), Mil and Denk, (2015) and Şen and Silahşör, (2018). The questions prepared were finalized by taking the opinions of two expert researchers. Research questions are as follows:

1. What are the reasons for choosing the tourists coming to the region?

2. Are there any local foods in your menu?

3. Have you had local foods in your menu before? 
4. Are local foods / products in demand in your business?

5. What are the known local dishes? If yes, why are meals not served? (Is it not preferred, are it difficult to make, are the materials expensive, etc.)

6. Where do you supply local dishes from?

7. What should be done to promote the local dishes of Şarköy?

The open and closed-ended questions obtained from the participants were examined, the expressions were coded and the results were tried to be reached by analyzing the content according to these encodings. The research consists of face-toface semi-structured interviews with 8 restaurant officials. Interview interviews were held between 10-26 January 2020. The results of the interview consisting of voice recording and notes were reported in detail and analyzed by descriptive analysis method.

\section{Result}

Within the scope of the research, it was observed that all of the officials were business owners. All of the companies interviewed are independent and do not depend on any chain business. As in the study of Şen and Silahşör, it has been determined that the majority of the authorities have considerable experience, but they do not hand over the enterprises to the professionals. In addition, it is observed that business executives are mostly high school graduates.

It has been determined that the tourists visiting the Şarköy region are predominantly made up of tourists who make cheap holiday plans, the blue flag of the sea is a major factor, and it also has a tourist structure that is described as a summer house. It has been determined that the operators do not generally include local foods in their restaurants. However, it is seen that two women entrepreneurs who have entered the sector in recent years have been operating more effectively in local cuisine. Vegetable dishes, olive oil dishes and appetizers are found in the menus of these businesses. It was understood that half of the enterprises did not use local foods in the previous periods, but used olive oil in many areas. It has been observed that a business that previously offered local dishes terminated the practice due to low demand. It has been determined that the few businesses that offer local dishes are generally satisfied with the sales. However, the reason is thought to be the small number of restaurants offering local products. According to the results, it has been observed that half of the restaurant businesses do not have a demand for local food, while the demand for local products comes from local consumers. It is also understood that the demand for fish meatballs among local products is high. At the same time, according to the findings obtained from the authorities, there are a lot of local foods in Şarköy and they are not offered in restaurants due to low demand. It has been understood that the construction phase of some local dishes is difficult and cannot be made due to high materials. It was concluded that the supply of materials in the preparation of local dishes is generally made first-hand and the emphasis is placed on fresh and natural products.

As suggestions to institutions and organizations, in the light of the information obtained from the participants, it has been seen as the provision of municipal advertising support for the promotion of local dishes, the general promotion of the Şarköy region, the organization of gastronomy festivals and participation in festivals.

As suggestions to researchers, there is a limitation as it is limited to the region used as the sample in the study. In the context of gastronomic tourism, choosing a 
different destination where local dishes are served and examining the relationships between them may be appropriate in terms of evaluating the factors. In addition, the fact that the 8 participants interviewed in the study have only restaurant stakeholders creates a limitation, and asking experts in the region on the subject will help develop suggestions.

\section{Giriş}

21. yüzyılın ilk birkaç yılında turizm endüstrisi içerisinde arz ve talepte farklılıkların oluştuğu görülmektedir. Düşük maliyetli havayolları, internetin yaygın kullanımı ve turizm üzerindeki etkileri, daha sık tatillere gitme isteği ve farklı destinasyon bölgelerini ziyaret etme isteği gibi yeni trendler, turizm endüstrisi içerisinde görülmeye başlanmıştır (López-Guzmán ve Sánchez-Cañizares, 2011). Bireylerin gelir düzeyinin yükselmesi ile birlikte, boş zaman ve eğitim seviyeleri artmış, ulaşım da kolaylaşmıştır. Yaşanan gelişmeler sonucunda, 21. yüzyılın ilk döneminde, turistlerin yeni destinasyon bölgeleri ve yeni deneyimleri keşfetme isteğinin de giderek artış gösterdiği söylenebilir.

Farklı turizm deneyimlerine ve yiyecek-içecek ile ilgili cazibe merkezlerine artan bir ilgi görülmektedir. Tatildeyken, tarihi mekânları ve müzeleri ziyaret ederken yerel yemek kültürü ile tanışmak mirasın tümünden faydalanıldığını gösterir (Hjalager ve Richards, 2002). Yerel yemek kültürü turist açısından tatmin edici boyutta ise, turist tekrar yaşadığı yere döndüğü zaman çevresine beğendiği tatları iyi bir şekilde anlatabilir ve diğer tüketicilerin ilgisini çekebilir. Akçin (2016) çalışmasında ağızdan ağıza pazarlamanın önemine vurgu yapmış, tüketicinin ürün hakkındaki olumlu söylemlerinin maliyetsiz bir biçimde reklam oluşturduğunu belirtmiştir.

Bölgenin kültürünü öğrenmek amacı ile ziyaret eden turist, bölge yiyecekiçeceklerinden de tadarak turizm olgusu içerisinde farklı alanları da öne çıkarmış olur ve bu sayede bölge ekonomisi de gelişim göstermiş olur (Şen ve Silahşör, 2018). Gelişen ekonomi ile yerel halk ve bölgede bulunan işletmeler turistin talebine karşılık verebilmek adına kaliteyi daha yukarı taşımak isteyebilir. Bertella (2011) gastronomi turizmi kapsamındaki işletmelerin her zevke uygun duyuları teşvik edebileceğini belirtmiştir. Ayrıca bölgesel yiyecek-içeceklerin kültürel bir değeri olduğunu aktarmış, yemek kültürünü bölgenin bir ifade biçimi olarak görmüştür. Aynı zamanda, Yüncü (2009) bölgeye özgü yiyecek-içeceklerin bölge için fark yaratıcı bir unsur olduğunu, günümüz insanlarının sadece karnını doyurmak amaçlı değil, farklı tadım deneyimleri yaşama isteği ile dışarıda yemek yediklerini belirtmiştir.

Türk, Fransız ve Çin mutfak grupları gastronomi alanında uzmanlaşmış kişiler tarafından dünya üzerindeki en zengin çeşitliliğe sahip mutfaklar olarak görülmektedir (Yergaliyeva, 2011). Şarköy kendine özgün, çeşitli tarımsal ürünlere sahip deniz kıyısında İstanbul'a yakın küçük bir yerleşim yeri olarak öne çıkmaktadır (Kiper, vd., 2011). Bu sebeple de yemeklerde tarımsal ürünlerin sıkça kullanıldığı görülmektedir. Özgün tatları ile Şarköy, sürdürülebilir gastronomi anlamında da kendine önemli bir yer bulabilir. Kılıçhan (2015) çalışmasında, kendine has lezzete sahip ve ekolojik anlamda sürdürülebilirliğini devam ettiren her bir yiyecek-içeceğin, yüzyıllar içerisinde oluşmuş beceri, akıl ve yaratıcılık eseri olduğunu aktarmıştır.

Alan yazın incelendiğinde benzer çalışmaların var olduğu, ancak İstanbul'a yakın ve turistik bir tatil merkezi olan Şarköy yöresi ile ilgili çok fazla çalışma bulunmadığı saptanmıştır. Yöresel yiyecek-içeceklerin, bölgedeki restoranlarda sunulması düzeyinin belirlenmeye çalışıldığı bu çalışma içerisinde gastronomi turizmi kavramı açıklanmış, yöresel yemek kültürüne ve Şarköy yemek kültürüne değinilmiştir. Bu doğrultuda Şarköy yöresindeki restoran yöneticileri ile görüşme gerçekleştirilmiştir. 
Çalışma sonuçlarının literatüre önemli katkı sağlayacağı, restoran yetkilileri için de değerli bir rehber olacağı düşünülmektedir.

\section{Literatür Taraması}

\subsection{Gastronomi ve Gastronomi Turizmi}

Turizm destinasyon sayısı arttıkça rekabet de üst seviyelere ulaşmaktadır. Yerel turizm hareketleri, turisti destinasyon bölgesine çekebilmek için değerli bir ürün ve faaliyet kaynağı durumuna ulaşmıştır. Gastronomi sadece turist deneyimi olarak değil, aynı zamanda farklı toplumlar içerisinde önemli bir kimlik kaynağı haline gelmektedir (Hjalager ve Richards, 2002). Ekonomik İşbirliği ve Kalkınma Örgütü (OECD) (2014) gastronomi deneyimini başka bir kültür içine katılan ve kendi kimliği hakkında bilgiye sahip insanların ve bulundukları yerler ile ilişki içinde olma durumu olarak değerlendirmiştir. Aynı zamanda kültür ve turizm arasındaki ilişkinin turizmin büyüme hızına olumlu etki yaptığını da eklemiştir.

Geleneksel mirasa dayalı yaratıcılıkların, maddi olmayan kültüre ve çağdaş yaratıcılığa dayalı yeni turizm biçimleriyle artan önemini görmekteyiz. Gastronomi turizmi bu düşünce ile ilgili ilk sıralarda görülebilir. Kültürel mirası, turizm içerisinde özel bir kimlik belirtisi olarak görmüş, yiyeceğin kimlik arayışında önemli bir faktör olarak öne çıktığını belirtmiştir (Hewison, 1987). Ayrıca yemek insanların temel bir ihtiyacıdır ve bu sebeple en yaygın kimlik belirleyicilerinden olması durumu hiç de şaşırtıcı hale getirmemektedir. Insanlar fizyolojik, psikolojik ve sosyolojik anlamda da talep ettiği yiyecekleri belirlemiş olarak görülebilirler. Iyer (2000) insanların turizm hareketleri arttıkça tükettikleri yemek miktarı da buna bağlı olarak artacaktır. Bazı yiyecek-içecek türlerinin belirli yörede bulunması ile artan gıda hareketliliği ve mutfak farklılıkları, turist için yöreyi cazibe merkezi haline dönüştürmektedir. Aynı zamanda, turistlerin farklı yörelerde karşılaştıkları yiyecek-içeceklere talep oluşturduğunu ve gastronomi hareketine katkıda bulunduklarını belirtmiştir.

Dünya üzerinde turizm aktivitelerinden gün geçtikçe daha fazla gelir elde etmeye çalışan paydaşlar, turistik ürün çeşitlendirilmesi ve sürdürülebilirliği adına cazibe ve çekiciliği artırmaya yönelik çalışmalar yapmaktadırlar. Bu anlamda gastronomi turizminin de önemi artmakta ve paydaş ülkelerin ekonomisine katkı sağlamaktadır (Mil ve Denk, 2015). Gastronomi turizminin ortaya çıkış sürecini etkileyen unsurlar olarak, turistlerin her geçen gün artan güçlü ve eğlenceli tatiller talep etmesi önemli bir rol oynamıştır (Getz, 2000). Gastronomi turizmi gibi diğer turizm aktivitelerine katılım taleplerinin artışını etkileyen önemli faktörler ise, modern çağ insanlarının çalışma sürelerinin kısalması ve çok daha fazla para kazanması olduğu düşünülmektedir. Insanların yemek kültürleri, yerel yaşamlarından ayrılmaz bir parça olarak düşünülebilir. Yiyecek ve içecekler; bir toplumun tarihini, kültürünü ve ekonomisini oluşturmakta ve o toplumun yaşam biçimiyle olgunlaşmaktadır (Mitchell ve Hall, 2006). Yöreyi ziyaret eden turistlerin de yiyecek içecek konusunda bölge ürünlerinden tatmin olduğu süreçte yörenin gastronomi turizmi anlamında gelişim göstereceği öngörülebilir. Yöreyi ziyaret eden turistler tamamen kendi isteklerine yönelik bir tatil geçirme eğiliminde oldukları süreçte, güvenli, makul fiyata sahip, sağlık açısından uygun gıdalara intiyaç duymaktadırlar. Buna istinaden her bir toplum, kendine ait olan mutfak kültürünü turizm perspektifinde değerli hale getirerek pazarlayabilmelidir (Albayrak, 2013). 


\subsection{Yöresel Yemek Kültürü}

Günümüzde turistlerin, gittikleri yöreye özgü yiyecek içecek ve diğer gıda ürünleri ile daha fazla ilgilendikleri söylenebilir. Tatil amacıyla yöre seçimi yapan turistler için, yöre yemek kültürü önemli bir faktör haline gelmektedir (McKrecher, vd., 2008). Buna ek olarak, özellikle yöresel ürünlerin tadımı ile ilgilenen farklı bir turist türünün ortaya çıktığı görülmektedir (Kesici, 2012). Pek çok turist, gastronomiyi bir katılım deneyimi olarak algılamaktadır. Yöresel yiyecek içecekleri olduğu yörede tatmayı, yörenin kültürü hakkında bilgi sağlamanın bir aracı olarak görmektedir (Chang, vd., 2010). Yöresel yemek kültürü, turistin bulunduğu destinasyon alanının bir parçası, turizm teşviki için önemli bir unsur, yerel ekonomi için bir kalkınma aracı ve tüketim modellerine etki eden bir unsur olarak kabul görmektedir (Tikkanen, 2007). Bu durumda gastronomi kültürünün tanıtımında yöredeki paydaşların rolünün önemi ortaya çıkmaktadır. Ürün kalitesi, yeterliliği, genel damak zevkine uygunluğu adına standartların belirlenmesi, yöresel ürünlerin değerlenmesine ve ekonomik kalkınmaya katkı sağlayabilir. Yapılan gastronomi festivalleri, yiyecek içecek tanıtım etkinlikleri, seyahat etmek için bir sebep arayan bir insan topluluğunu hedef almaktadır. Yani bu durum; ortada bir pazar, bir talep olması ile ilgilidir (Deneault, 2002).

Kültürel cazibe merkezlerinin sınıflandıııldığı durumda, yöresel gastronomi rotaları da belirli bir kültürel turizm ürünü olarak tanımlanmaktadır (Munsters, 1994). Yöresel yiyecek ve içecekler sunan bir yöre, tarihi ve özel bir yapıya sahip olmasa dahi turistin ilgisini çekmektedir. Turistin yöresel ürünlere ilgisinden yola çıkarak gastronomi turizminin ne denli öneme sahip olduğu görülebilir, paydaşların birlikte hareket ederek yapacakları stratejik hamlelerin yörenin refahına katkı sağlayacağı söylenebilir. TÜRSAB (t.y.) gastronomi raporu verilerine göre, dünya üzerinde seyahat hareketlerine katılan sayısının 1 milyarı aştığı ve turistlerin \%88,2'si bir destinasyon alanının seçiminde, yemeklerin önemli olduğunu vurgulanmıştır.

Farklı bir turistik ürün olarak öne çıkan yavaş şehirler, yerel vatandaşlar ve turistlerin yaşam kalitesini artırmak için genel anlamda yaşamı yavaşlatmaya kendilerini adamışlardır. Yavaş şehirler aynı zamanda turistlere küreselleşmiş varyasyonlar yerine "gerçek" yerel yemekleri tatma şansı sunmaktadırlar (Hjalager ve Richards, 2002). Sürdürülebilirliğin dünya üzerinde gelinen noktada çok önemli bir yere sahip olması ile birlikte, yavaş yemek akımına uyan sürdürülebilir restoranlar da önemli hale gelmektedir. Sürdürülebilir restoranlar ve yavaş yemek kültürü ile dünya üzerindeki önemli mutfak sanatları korunmakta, aynı zamanda biyolojik çeşitlilik ve yerel çiftçilik olgularının da artması sağlanmaktadır (Sünnetçioğlu, vd., 2012).

\section{3. Şarköy Mutfağı ve Yöresel Yemekleri}

Şarköy yöresinin başlıca geçim kaynakları arasında tarım gelmektedir. Mikro klima özelliğinin sağladığı avantajlar ile yerel halk çok yönlü tarım yapabilmektedir. Şarköy yöresi, tarımsal üretimde zengin potansiyele ve ürün çeşitliliğine sahiptir (Trakya Kalkınma Ajansı, 2013). Yörenin en yüksek gelir sağladığı ürünler zeytin ve üzüm olarak görülmektedir. Ayrıca kiraz, ceviz ve elma gibi ürünler de öne çıkmaktadır. Tekirdağ'ın sadece Şarköy yöresinde üretilen zeytinden yüksek miktarda zeytinyağı yapılmaktadır. Aynı zamanda diğer yüksek üretime sahip ürünü üzümden de yine yüksek miktarda şarap yapılmaktadır. Gaziköy ve Uçmakdere köylerinde bağ ve zeytinlik olmayan yerlerde arpa ve buğday tarımı ile sıkça uğraşılmaktadır (Özyavuz, 2010). 


\subsection{Tekirdağ/Şarköy Destinasyonu}

Tekirdağ merkezine uzaklığı 84 km. olan Şarköy yöresi batı kısımda kalmış, ancak son yıllarda çok fazla insanın bilgi sahibi olmaya başladığı güzide bir destinasyon alanı olarak göze çarpmaktadır. Şarköy'ün toplam nüfusu 2018 yılı "Adrese Dayalı Nüfus Kayıt Sistemi" sonuçlarına göre 32,565 kişidir. Bu nüfusun 20.506 kişisi İlçe merkezinde, 12.059 kişisi ise Kasaba ve Köylerde bulunmaktadır. Yüz ölçümü 481 km2 olan Şarköy yöresinin güney ve doğu taraflarını Marmara denizi, batı tarafını Çanakkale ilinin Gelibolu ilçesi, kuzey kısımlarını da Merkez ve Malkara ilçesi kapsamaktadır (Kiper vd., 2011). Uzun yıllardır mavi bayraklı plajlara sahip olan destinasyon alanı son yıllarda özellikle yaz mevsiminde İstanbul halkının önemli derecede dikkatini çekmektedir. Yaklaşık 30.000 olan nüfus sayısı yaz aylarında 300.000 ile 400.000 civarlarına ulaşabilmekte ve yerel halk için önemli geçim kaynağı olmaktadır (DHA, 2015).

İlçenin genel olarak iklimi Akdeniz iklimine yakın geçmektedir. Yaz ayları, genel olarak sıcak ve nemli, kış ayları ise Balkan şeridinden gelen soğuk hava dalgaları sebebiyle soğuk, aynı zamanda ılık ve yağışlı geçmektedir. Ancak güncel olarak 2015 yılından sonraki süreçte kışların çok daha soğuk geçtiği görüşü hâkim olmakta, ılık ve yağışı havaların yerini karlı ve şiddetli soğuklara bıraktığı görülmektedir (Küçükaltan ve Ultanır, 2012).

Çalışma yapılan alanın en önemli geçim kaynakları, bağcılık, tarım, hayvancılık ve turizm olarak değerlendirilmektedir. Yılın yaklaşık 3 ile 4 aylık sürecinde halkın geneli turizme hizmet etmekte ve ekonomik gelirlerini artırmaya çalışmaktadırlar. Tarımsal olarak verimli topraklara sahip olan bölgede üretilen üzümün sirke ve şarap yapımında kullanıldığı bilinmektedir. Zeytin ise genel olarak zeytinyağı yapımında kullanılmaktadır. İklimin elverişliliği sebebiyle yetiştirilen çeşitli meyveler, başta İstanbul olmak üzere çevre illere pazarlanmaktadır. İlçe bilhassa Mürefte kasabasında birçok şarap fabrikasına ev sahipliği yapmaktadır (Anonim, 2018).

Tablo 1: Şarköy Tarımsal Turizm Aktiviteleri

\begin{tabular}{|c|c|c|}
\hline & & \\
Tarımsal & Şarapçılık etkinliklerine katılma & \\
Turizm & İpekböcekciliği etkinliklerine katılma & Uçmakdere \\
Arıcılık etkinliklerine katılma & Mürefte \\
& Zeytincilik etkinliklerine katılma & Gaziköy \\
& Meyvecilik etkinliklerine katılma & Yeniköy \\
& & \\
& & \\
& & \\
\end{tabular}

Kaynak: (Çakır ve Çakır, 2012).

Tablo 1'e göre tarımsal turizm faaliyetlerinde ilgili bölgede yapılan etkinlikler görülmektedir. Kendine ait bir lezzete sahip her yöresel yemekte yüzyıllar içerisinde olgunlaşmış bir birikim, yetenek ve zekâ bulunmaktadır. Eko-gastronomideki temel amaç, sürdürülebilirliği sağlayarak gastronomi kültürünü devam ettirebilmektir. Ekogastronomi, yerel tarımı desteklemekte, standarda uygun olmayan üretimi önlemekte 
ve bu şekilde çekicilik unsurlarına katkı sağlamaktadır. Ayrıca yerel toplumu turizm ve tarım sektörleri açısından güçlendirir, yiyecek çeşitlerine marka ve kimlik oluşturur ve çevreye duyarlığı alt ve üst yapı oluşmasına olanaklar sağlar (Kılıçhan, 2015).

Şarköy yöresi var olan farklı yiyecek çeşitleri ile eko-gastronomi anlamında yeterli bir yer olarak öne çıkmaktadır. Turistler çoğunlukla sahil şeridinde bulunan restoranlarda birbirinden ilginç yeni tadımlar yapabilirler. Şarköy'ün yöresel yiyeceklerine ise aşağıdaki tablolarda verilmiştir.

\section{Tablo 2: Şarköy Mutfak Kültüründeki Yöresel Çorbalar}

ÇORBALAR

\begin{tabular}{ll}
\hline Balık çorbası & Yuvalama \\
\hline Papara & Sütlü tirit \\
\hline $\begin{array}{l}\text { Rakka kaşa (Süt, } \\
\text { Ayran, Un) }\end{array}$ & Fasulye çorbası \\
\hline Tarhana kavardisita & Mürdük çorbası \\
\hline $\begin{array}{l}\text { Uğmaç çorbası } \\
\text { (rusnisa) }\end{array}$ & Soğan, salça, un, tereyağ, toz biber, karabiber, tuz \\
\hline Bulgur çorbası & İnce bulgur, soğan, domates, salça, yağ, nane, tuz \\
\hline Kesme çorba & Soğan, tereyağ, toz biber, karabiber, un, su, tuz \\
\hline \multicolumn{1}{c}{ Kaynak: (Çakır ve Çakır, 2012; Anonim, 2012). }
\end{tabular}

Tablo 2'den elde edilen verilere göre yöredeki çorba kültüründe, içerisinde un bulunan çorbaların çok fazla olduğu görülmektedir. Burada, genel Tekirdağ mutfak kültürü içerisinde bulunan çorbalar da yer almaktadır. Tekirdağ mutfak kültüründe olduğu gibi, tamamen Şarköy yöresine ait olan çorbalarda da çok fazla tahıl ürünü kullanıldığı, en fazla ise un kullanıldığı görülmektedir.

Tablo 3: Şarköy Mutfak Kültüründeki Yöresel Sebze Yemekleri

\begin{tabular}{ll}
\hline SEBZE YEMEKLERI & \\
\hline Kabak tikvenik & Kesik kızartması \\
\hline Ot köftesi & Kabak kayık \\
\hline Sütlü patlıcan & Soğan kapama \\
\hline Patıcan kapama & Dilim kabak \\
\hline Ispanakı borani & Patlıcan ekşilisi \\
\hline
\end{tabular}

Kaynak: (Çakır ve Çakır, 2012; Anonim, 2012).

Tablo 3'te yörenin mutfak kültüründe önemli yer tutan sebze yemekleri sıralanmıştır. Yörede zeytinyağı üretiminin yapılması sebebiyle birçok sebze yemeğinde zeytinyağı kullanılmaktadır. Ayrıca tarımsal alanların ve verimli topraklarının fazlalığı sebebiyle çeşitli sebze yemeklerinin de yapıldığı görülmektedir. Ayrıca literatüre girmemiş daha fazla sebze yemeklerinin de bulunduğu düşünülmektedir.

Tablo 4: Şarköy Mutfak Kültüründeki Yöresel Et Yemekleri

\begin{tabular}{ll}
\hline ET YEMEKLERI & \\
\hline Yaprak kebabı & Ciğer sarma \\
\hline Göceli kapama & Oğlak dolması \\
\hline Piliç dolması & Oğlak kapama \\
\hline Tavuk kapama & \\
\hline \multicolumn{1}{c}{ Kaynak: (Çakır ve Çakır, 2012; Anonim, 2012). }
\end{tabular}


Tablo 4'te Şarköy mutfağına has yöresel et yemekleri verilmiştir. Küçük, merkezden uzak kırsal bir yöre olan Şarköy'de, nüfusun büyük çoğunluğu küçükbaş ve kümes hayvanları yetiştirmektedir. Tablo, yerel halkın rahat bir şekilde ulaşabildiği ürünü değerlendirdiğini göstermektedir. Yöresel et yemeklerine bakıldığında genel olarak küçükbaş hayvancılığa dayalı bir et yemeği kültürünün olduğu anlaşılmaktadır. Ayrıca tavuk eti ile de farklı lezzetler yapıldığı görülmektedir.

Tablo 5: Şarköy Mutfak Kültüründeki Yöresel Balık Yemekleri

\begin{tabular}{ll}
\hline BALIKLAR & \\
\hline Garoz & Lakerda \\
\hline Balık köftesi & Balık dolgusu \\
\hline Kolyoz balığı tuzlama & \\
\hline
\end{tabular}

Kaynak: (Çakır ve Çakır, 2012; Anonim, 2012).

Tablo 5 verilerinde bir sahil kasabası olan Şarköy'de, elde edilen balıkların çeşitli yöntemler kullanılarak konserve yapıldığı görülmektedir. Tamamen deniz kenarı olan yörede önemli derecede taze balık tüketimi de vardır. Buradan yola çıkarak, yerel halkın elde ettiği balıkların bir kısmını konserve olarak da sakladıkları saptanmaktadır.

Tablo 6: Şarköy Mutfak Kültüründeki Yöresel Hamur İşleri

\begin{tabular}{ll}
\hline HAMUR IŞLERI & \\
\hline Karnıyarık böreği & Yoğurtlu Arnavut pidesi \\
\hline Sparnik & Fırın lokumu \\
\hline Gacal mantıSı & Köbete \\
\hline Boş dolama & Gömme \\
\hline Cizleme & Etli kordu (kurmindik) \\
\hline Ispanak kodrusu & Kabak böreği \\
\hline Peksimet & Laklör \\
\hline Saraylıya & Yanıç \\
\hline Kuru kus kus kapama & Tavuklu akıtma \\
\hline Zennik & Nohutlu ekmek \\
\hline Saç örgüsü çöreği & Asker turtası \\
\hline Bayram çöreği & Topka \\
\hline \multicolumn{1}{c}{ Kaynak: (Çakır ve Çakır, 2012; Anonim, 2012). }
\end{tabular}

Tablo 6'da Şarköy yöresinin yöresel hamur işlerinde çeşitlilik barındırdığı görülmektedir. Yöre halkı içerisinde çok fazla muhacir bulunması, göçtükleri dönemlerdeki kendi tarifleri ile yöreye gelmeleri etkin rol oynamıştır. Aynı zamanda iklimi ve arazi yapısı nedeniyle, tarımsal faaliyetler sonucunda yörede un ile çok fazla yemek çeşidi yapılmaktadır. Bu da yörede hamur işlerinin fazla olmasının ayrı bir göstergesi olarak düşünülebilir.

Tablo 7: Şarköy Mutfak Kültüründeki Yöresel Meze ve Zeytinyağlılar MEZE VE ZEYTINYYAGLILAR

\begin{tabular}{ll}
\hline Fava & Partal çılbır \\
\hline Soğan çılbırı & Yaz tunçiliği \\
\hline Mürdüklü & Yaprak sarması \\
\hline Ciğerli biber dolması & Karides salatası \\
\hline Yumurta dolgusu & Guridalı biber \\
\hline Kapiçka fasulye & Kış tunçiliği \\
\hline
\end{tabular}

Kaynak: (Çakır ve Çakır, 2012; Anonim, 2012). 
Tablo 7'den görüldüğü üzere yöresel yemek kültüründe birçok farklı zeytinyağlı meze ve yemekler bulunmaktadır. Yörede zeytinyağlı, hayvansal ürünler kullandığı görülmektedir.

Tablo 8: Şarköy Mutfak Kültüründeki Yöresel Tatlılar

\begin{tabular}{ll}
\hline TATLILAR & \\
\hline Dilberdudağı & Ayva aşı \\
\hline Gazoz tatısı & Cevizli şeker böreği \\
\hline Oturtma & Nişan kurabiyesi \\
\hline Peynir helvası kurabiyesi & Pekmezli zerde \\
\hline Pehle & Pekmez helvası \\
\hline Reşediye (dedem böceği) & Tezpişti \\
\hline Merdane baklavası & Kaz boğazı \\
\hline Kuşburnu kurabiyesi & Yumurta helvası \\
\hline Mursallı örgüsü & \\
\multicolumn{2}{c}{ Kaynak: (Çakır ve Çakır, 2012; Anonim, 2012). }
\end{tabular}

Tablo 8'de görüldüğü üzere yöre halkının, meyve tatıları ve helvalara önem verdiği görülmektedir. Tarım ürünlerinin, tatlılarda da kullandığı görülmektedir. Yörenin verimli toprakları nedeniyle halkın, tatlı çeşitlerinde de meyveye sıkça yer verdiği anlaşılmaktadır.

Tablo 9: Şarköy Mutfağında Kış Hazırlıkları

\begin{tabular}{ll}
\hline KIŞ HAZIRLIKLARI & \\
\hline Yağlı turşu & Başı bağlı patııcan turşusu \\
\hline Erişte & Teke peyniri \\
\hline Kesme makarna & Kuru yufka \\
\hline Şıra tarhanası & Bulama \\
\hline Göce & Katık \\
\hline Pekmezli kabak reçeli & Kiraz reçeli \\
\hline Kaynak: (Çakır ve Çakır, 2012; Anonim, 2012). &
\end{tabular}

Tablo 9'da görüldüğü üzere yöre halkı, kış hazırlıkları kapsamında yine tahıl ürünleri, sebze ve meyveyi sıkça kullanmaktadır. Buradan yola çıkıldığında, yöre halkının yaz sezonunda ürettiği birçok ürünü, kış hazırlıkları içinde kullanmakta olduğu görülmektedir.

\section{Yöntem}

\subsection{Araştırmanın Amacı ve Önemi}

Bu çalışmanın temel amacı, Tekirdağ'a bağlı Şarköy yöresinde bulunan restoranların, bölgeye ait yöresel yemeklerinin menülerinde yer alma durumunu tespit edip, gastronomi turizmi çerçevesinde değerlendirmektir. Bu çalışmada nitel araştırma yöntemi kullanılmıştır. Çalışma için nitel araştırma yönteminin seçilme sebebi, araştırmayı yapan kişinin katılımcı olarak görüşmeler yaparak daha derin bilgiler elde edebilmesi, araştırma konusunun alanında incelenmesi, algılanan tüm verilerin ortaya konabilmesi ve araştırmanın esnekliğinin bulunmasıdır (Yıldırım ve Şimşek, 2008; Karasar, 2011). Özellikle gastronomi turizminin gelişmesi, yöresel kalkınmanın 
öneminin artması, turistlerin farklı lezzetler araması ve bu sebeple daha fazla seyahat etmeye başlaması bu yöresel çalışmayı önemli hale getirmektedir.

\subsection{Veri Toplama Aracı}

Araştırmada kapsamında yöredeki 22 restoran işletmesi bulunmaktadır. Veriler yöredeki görüşmeyi kabul eden 8 restorandan yarı yapılandırılmış görüşme tekniği ile toplanmıştır.

Araştırmada veri toplama aracı olarak yarı yapılandırılmış görüşme formu kullanılmıştır. Bu görüşme tekniğinde araştırmayı yapan kişi, önceden hazırladıkları soruları karşı tarafa sormakta ve konunun derinliklerine ulaşmayı hedeflemektedir (Karasar, 2005). Nitel araştırmalarda, araştırmacının kendi düşüncelerini karşı tarafa empoze etmemesi adına, yapılandırılmış değil de yarı yapılandırılmış ya da yapılandırılmamış görüşme formları kullanılmaktadır (Mil, 2007). Yarı yapılandırılmış görüşmede 7 ana soru rehberlik etmekte ayrıca çalışmanın amacına uygun farklı sorularda sorulabilmektedir. Görüşme formunun hazırlanmasında, Aslan, vd. (2014), Mil ve Denk, (2015) ve Şen ve Silahşör, (2018) çalışmalarından yararlanılmıştır. Hazırlanan sorular 2 uzman araştırmacının görüşü alınarak son haline getirilmiştir. Araştırma soruları ise aşağıdaki gibidir:

1. Yöreye gelen turistlerin tercih sebepleri nelerdir?

2. Menünüzde yöresel yemekler var mıdır?

3. Daha önce menünüzde yöresel yemekler bulundurdunuz mu?

4. İşletmenizde yöresel yemekler/ürünler talep edilmekte midir?"

5.Bilinen yöresel yemekler hangileridir? Varsa sunulmayan yemekler neden sunulmamaktadır? (tercih mi edilmiyor, yapımı mı zor, malzemeler mi pahalı vb.)

6. Yöresel yemeklerin malzeme tedariğini nereden yapmaktasınız?

7. Şarköy yöresel yemeklerini tanıtmak için neler yapılmalıdır?

Katılımcılardan elde edilen açık ve kapalı uçlu sorular incelenmiş, ifadeler kodlanmış ve bu kodlamalara göre içerik analizi yapılarak sonuçlara ulaşılmaya çalışımıştır. Araştırma 8 restoran yetkilisi ile yüz yüze yapılan yarı yapılandırılmış mülakatlardan oluşmaktadır. Mülakat görüşmeleri, 10-26 Ocak 2020 tarihleri arasında gerçekleştirilmiştir. Ses kaydı ve notlardan oluşan görüşmeye dair sonuçlar ayrıntılı şekilde raporlanmış ve betimsel analiz yöntemi ile analiz edilmiştir.

\subsection{Bulgular}

Tablo 9 incelendiğinde işyeri yetkilerinin hepsinin işveren olduğu görülmektedir. Buradan işletmelerin profesyonel bir yönetime tabi olmadıkları görülmektedir. Ayrıca işletmelerin büyük çoğunluğunu yönetenlerin ise lise mezunu oldukları saptanmıştır. Kadın girişimcilerin yeni yeni artmaya başladığı da görülmektedir. Erkek yöneticilerin ise yüksek bir mesleki tecrübeye sahip oldukları görülmektedir. 
Tablo 9: Katılımcılara Yönelik Demografik Bilgiler

\begin{tabular}{|c|c|c|c|c|c|}
\hline Katılımcılar & Cinsiyet & $\begin{array}{l}\text { Eğitim } \\
\text { Düzeyi }\end{array}$ & Pozisyon & Yaş & $\begin{array}{l}\text { Mesleki } \\
\text { Tecrübe }\end{array}$ \\
\hline K1 & $E$ & Lise & İşveren & 39 & $18 \mathrm{YII}$ \\
\hline K2 & $E$ & Üniversite & İşveren & 44 & $17 \mathrm{YII}$ \\
\hline K3 & $\mathrm{K}$ & Üniversite & İşveren & 39 & $4 \mathrm{YIl}$ \\
\hline K4 & $E$ & Lise & İşveren & 46 & $30 \mathrm{YIl}$ \\
\hline K5 & $E$ & Ortaokul & İşveren & 40 & $20 \mathrm{YIl}$ \\
\hline K6 & $\mathrm{K}$ & Lise & İşveren & 38 & $2 Y_{I I}$ \\
\hline K7 & $E$ & Lise & İşveren & 34 & $15 \mathrm{YIl}$ \\
\hline K8 & $E$ & Lise & İşveren & 38 & $15 \mathrm{YIl}$ \\
\hline
\end{tabular}

Yöreyi ziyaret eden turistlerin Şarköy'ü tercih etme sebepleri: Konu hakkında görüş bildiren katılımcıların tamamı, Şarköy'ün tercih edilme sebebinin ucuz tatil yapabilme isteğinden kaynaklandığını belirtmişlerdir. Ayrıca katılımcılar gelen turistlerin yazlıkçı turistler olduklarını belirtmişler, kışları yörenin boş kaldığına vurgu yapmışlardır. Yöneticilerin 4'ü direkt İstanbul'a yakınlığı sebebiyle Şarköy’ün turist çektiğini de vurgulamıştır. Aynı zamanda katıımcıların 7'si mavi bayraklı plajlara sahip Şarköy'ün turisti önemli ölçüde etkilediğini ve çektiğini belirtmişlerdir. Yine birçok katılımcı, doğasının ve günlük kiralık daire sayısının fazlalığının turist tercihinde etkin rol oynadığını aktarmıştır. Ayrıca bir katılımcının "Istanbul'a yakın bir yer ve mavi bayraklı plajı var. Doğası çok güzel. Konaklama ucuz, günlük kiralık daire ve pansiyon bulmak çok kolay" cümlesinin genel görüşü yansıttığını söyleyebiliriz.

İşletme menülerinde bulunan yöresel yemekler: Görüşme yapılan restoran yetkililerinin \%63'lük kısmı işletme menülerinde yöresel yiyeceklere yer vermediklerini belirtmişlerdir. Bir restoranın direkt olarak yöresel ürünler üzerine çalıştığı görülmüş, diğerlerinin de yöresel bazı ürünlere restoran menülerinde yer verdikleri saptanmıştır. İşletmelerin menülerinde yer verdikleri yöresel yemek türlerinin ise, genel olarak sebze yemekleri, zeytinyağlılar ve mezelerden oluştuğu görülmektedir. Aynı zamanda yöresel ürünler üzerine kurulu restoran işletmesinin, Tekirdağ ilinin genel tüm yöresel yemeklerine menülerinde yer vermeye çalıştıklarını belirtmiştir. Bir katılımcı görüşünde ise "Menümüzde birkaç sebze ve zeytinyağlı yemek çeşidi bulunmaktadır. Bunlar mücver, patııcan ekşili, ıspanak borani, ot köfte, fava, çılbır, kapiçka ve sarmadır" Şarköy yöresel yemeklerinin bazıları görülmektedir.

Daha evvelden işletme menülerinde bulunan yöresel yemekler: Görüşme dahilindeki işletme yöneticilerinin \%50'lik görüşü, daha önceki zamanlarda da yöresel yemekler bulundurmadıkları ile ilgilidir. Bir yönetici "Hayır bulundurmadık, çok fazla talep olacağını düşünmüyoruz. Zeytinyağını ise birçok çeşit içerisinde kullanıyoruz" ifadesinde bulunmuştur. Ek olarak bir başka yönetici görüşü ise, "Mücver, ot köfte, kabak karnıyarık yaptık daha önce. Çok fazla talep görmedi. Insanlar yöre yemeği hakkında çok fazla bir şey bilmiyor" görüşünü sunmuştur. \%38 oranındaki yönetici cevabı ise, işletmelerinde daha evvelden bugüne kadar yöresel yemekler bulundurdukları üzerinedir. Yöresel ürünleri restoranında sunan bir işletme sahibi ise, "Henüz yeni bir işletme sayılırız. Şu anda bazı yöresel ürünler mevcut. Illeride duruma göre sayı daha da fazla olabilir" yorumunda bulunmuştur.

İşletmelerde talep edilen yöresel ürünler ve yemekler: Yine konu hakkında görüş bildiren yöneticilerin \%50'si tüketicilerden yöresel yemeklerle ilgili herhangi bir talep gelmediğini belirtmişlerdir. Daha evvelden yöresel bazı ürünleri bulunduran bir 
restoran işletmesinin yöneticisi ise, "Daha önceden yöresel yemeklerden bazılarını satıyorduk. Talep düşüklüğü sebebiyle satışları durdurduk. Daha sonra tekrar soran müşterilerimiz oldu" yanıtını vermiştir. \%25'lik kısım ise, yöresel ürün müşteri portföyünü yerel halkın oluşturduğu bilgisini paylaşmışlardır. Bir işletme yöneticisi ise konu hakkında, "Evet talep oluyor. Balık restoranıyız ve özellikle balık köfteyi çok satıyoruz" cevabını vermiştir.

Şarköy'de bilinen yöresel yemekler ve sunulmayan yöresel yemeklerin sebebi: İşletmeler özellikle bu soru karşısında çok fazla sayıda yöresel yemek bulunduğundan bahsetmişlerdir. Ancak talep konusundaki eksikliğin bulunmasının, yöresel yemeklerin işletmelerde sunulmasına olumsuz etki yaptığını belirtmişlerdir. Ayrıca yapımı zor olan ürünler bulunduğunu ve fiyatı pahalı malzemelerin de bazı yemek türlerinin satışının yapılmasının önüne geçtiğini söylemişlerdir. Bir yetkili "Buraların paparası, uğmaçı, tiverniki, mücveri, oğlak kapaması meşhurdur. Ancak yerli halk bunları kendi için yapar. Sanıyorum ki talebi az" yorumunda bulunmuştur. Bir başka yetkili ise, "Çok fazla sayıda yöresel yemek var burada. Ancak birçoğu köylerde kaldı. Yapılması zor, hızı tüketilmesi gerekenler var, malzemesi pahalı olanlar var" bu şekilde görüş belirtmiştir. Yetkililerden bir tanesi de "Çok fazla yöresel yemek var. Ancak yerli halkın yöresel hamur işleri çok fazla. Iş̧letme bazında çok fazla yöresel ürün sunan bir yer yok burada. Çok tercih edilmediğini düşünüyorum" diye fikrini belirtmiştir.

Yöresel yemeklerin malzeme tedarik bilgileri: Katılımcıların yarısı yöresel ürünler satmadıkları için malzeme tedariki ile ilgili bu soru karşısında cevap vermişlerdir. Geriye kalan yetkililerin ise, yöresel ürünlerin tümünü ilk elden aldıkları anlaşılmaktadır. Genellikle Şarköy'ün köylerinden ürün tedariki yapıldığı görüşü belirtilmiştir. Konu hakkındaki bazı katılımcı görüşleri ise, "Yemeklerde kullandığımız malzemelerin büyük çoğunluğu Mürefte'nin köylerinden gelmektedir. Kadın destekçilerimizin ürünleridir genel olarak" ifadesinde bulunmuş, balık üzerine restoran işleten bir yetkili ise, "Bize balıklar ve diğer deniz ürünleri direkt denizden gelir. İlk elden ve taze bir biçimde" görüşünü belirtmişlerdir.

Yöresel yemeklerin tanıtımı için yapılması gerekenler: Soru hakkında tüm katıımcıların ortak görüşü olarak öne çıkan, Şarköy'ün tanıtımı ve yöresel yemekler yapan işletmelerin belediyelerce reklamının yapılmasıdır. Ayrıca katılımcıların yarısı ise gastronomi ile ilgili festivaller düzenlenmesi ya da bu tarz festivallere katılmak gerektiğini belirtmişlerdir. Yine bazı yetkililer, Şarköy'ün İstanbul'da ve çevre illerde tanıtımının önemli olduğuna vurgu yapmışlardır. Bir erkek yetkili "Yöresel yemekler satan işletmelere destek sağlanmalı, özellikle kadın girişimcilere. Öncelikle Şarköy’ü iyice tanıtmak gerekli. Burası Istanbul'a yakın küçük ve güzel bir sahil kasabası" yorumunu yapmış, bir başka yetkili "Festival gibi etkinlikler yapılmalı. Başka şehirlerde festivallere yöresel ürünlerle gidilmeli, tanıtılmalı. Belediye ekstra reklamlar yapmalı" söyleminde bulunmuştur. Bir başka işletme yöneticisi de yine "Çevre illere reklamlar yapılmalı. Insanları buraya getirebilmeli, daha fazla yöresel yemek işletmesi açılması desteklenmell" yorumunda bulunmuştur.

\section{Sonuç ve Öneriler}

Araştırma Tekirdağ ilinin Şarköy yöresinde bulunan restoranlar üzerine yapılmıştır. Restoran yetkilileri ile görüşmeler yapılmış, Şarköy'e ait yöresel yemeklerin restoran işletmelerinde bulunabilirliği ölçülmüştür. Ayrıca restoran yetkililerinin Şarköy yöresel yemeklerinin tanıtımı konusunda önerileri de alınmıştır. 
Araştırma kapsamında yetkililerin hepsinin işletme sahibi olduğu gözlenmiştir. Görüşme yapılan işletmelerin hepsi bağımsızdır ve herhangi bir zincir işletmeye bağımlı değillerdir. Şen ve Silahşör'ün çalışmasında olduğu gibi yetkililerin büyük çoğunluğunun önemli derecede tecrübe sahibi oldukları, ancak işletmeleri profesyonellere teslim etmedikleri saptanmıştır. Ayrıca işletme yetkililerinin çoğunlukla lise mezunu oldukları görülmekterdir.

Şarköy yöresini ziyaret eden turistlerin ağırlıklı olarak ucuz tatil planı yapan turistlerden oluştuğu, denizinin mavi bayraklı olmasının büyük etken olduğu, ayrıca yazlıkçı olarak nitelendirilen bir turist yapısına da sahip olduğu belirlenmiştir. İşletmecilerin restoranlarında genel olarak yöresel yemeklere yer vermediği tespit edilmiştir. Ancak sektöre son yıllarda giren iki kadın girişimcinin, yöresel yemekler konusunda daha etkin işletmecilik yaptıkları görülmektedir. $\mathrm{Bu}$ işletmelerinde genel olarak menülerinde sebze yemekleri, zeytinyağlılar ve mezelerin bulunduğu belirlenmiştir. İşletmelerin yarısının daha önceki dönemlerde de yöresel yemeklere yer vermedikleri, ancak zeytinyağını birçok alanda kullandıkları anlaşılmıştır. Daha evvel yöresel yemekler sunan bir işletmenin ise uygulamayı talep düşüklüğü sebebiyle sonlandırdığı görülmüştür. Yöresel yemekler sunan az sayıdaki işletmelerin de genel olarak satışlardan memnun olduğu belirlenmiştir. Ancak sebebinin az sayıdaki yöresel ürün sunan restoran olduğu düşünülmektedir. Sonuçlara göre restoran işletmelerinin yarısına yöresel yemekler ile ilgili bir talebin olmadığı görülmüş, yöresel ürüne talebin ise yerli tüketicilerden geldiği belirtilmiştir. Yöresel ürünlerden balık köfteye rağbetin yüksek olduğu da ayrıca anlaşılmaktadır. Aynı zamanda yetkililerden elde edilen bulgulara göre, Şarköy'de çok fazla yöresel yemek bulunmakta, talep düşüklüğü sebebiyle restoranlarda sunulmamaktadır. Yöresel bazı yemeklerin yapım aşamasının zorlu olduğu ve yüksek malzeme sebebiyle yapılamadığı anlaşılmıştır. Yöresel yemek yapımında malzeme tedarikinin genel olarak ilk elden yapıldığı ayrıca taze ve doğal ürünlere ağırlık verildiği sonucuna ulaşılmıştır.

Kurum ve kuruluşlara öneriler olarak, katılımcılardan elde edilen bilgiler ışığında yöresel yemeklerin tanıtımı için belediye reklam desteklerinin sağlanması, Şarköy yöresinin genel tanıtımının yapılması, gastronomi festivalleri yapılması ve festivallere katılım sağlanması olarak görülmüştür.

Zengin bir mutfağa sahip olan Şarköy'ün mutlaka bir gastronomi haritası çıkarılmalıdır. Ayrıca gastronomi turları yaygınlaştırımalı, yiyecek festivalle içecek festivalleri düzenlenmeli, ilçe bazında yöresel lezzetler ortaya çıkarılmalı, tanıtımına önem verilmeli ve Şarköy mutfak kültürünün gastronomi turizmi çerçevesinde değerlendirmeye daha fazla önem verilmelidir. Nasıl ki İtalya turizm tanıtımında kültürel mirasının yanında pasta olarak belleklere kazıdığı makarnayı ve pizzayı pazarlayabiliyorsa, Fransa şarap ile anılıyorsa, Şarköy'ün de çeşitli tanıtımlar ile gastronomik ürünleri tanıtılabilir. Aynı zamanda Şarköy'e özgü şarap ve zeytinyağı üretiminin de yöreye ekonomik bir değer oluşturduğu bilinmektedir (Kiracı, 2006). Türkiye'de Şarköy, özellikle zeytinyağı ve şarap gibi değerli ürünlerini daha fazla tanıtmak için çaba harcamalıdır.

Şarköy'e özgü değerli ürünleri olarak göze çarpan zeytin, zeytinyağı, üzüm, şarap ve sike gibi ürünlerine coğrafi işaret başvurusunda bulunulmadığı görülmektedir (Türk Patent, 2020). En kısa süre içerisinde bu ürünler adına yapılacak tesciller ilerideki dönemlerde gastronomi turizmi açısından avantajlar sağlayabilir.

Araştırmacılara öneriler olarak, çalışmada örneklem olarak kullanılan yöre ile sınırlı tutulduğu için sınırılık söz konusudur. Gastronomi turizmi bağlamında yöresel 
yemeklerin sunulduğu farklı bir destinasyon seçilerek aradaki ilişkiler incelenmesi aradaki faktörleri değerlendirmesi açısından uygun olabilir. Ayrıca çalışmada görüşülen 8 katılımcının sadece restoran paydaşlarının olması sınırlıık oluşturmakta olup, yöredeki uzmanlardan konu ile ilgili görüş istemek önerilerin geliştirilmesine yardımcı olacaktır.

\section{Kaynakça}

Akçin, C. (2016). Sağlık Hizmetlerinde Ağızdan Ağıza Pazarlamaya Yönelik Bir Alan Araştırması, Yayınlanmış Yüksek Lisans Tezi, İstanbul Gelişim Üniversitesi, İstanbul.

Albayrak, A. (2013). Farklı Milletlerden Turistlerin Türk Mutfağına İlişkin Görüşlerinin Saptanması Üzerine Bir Çalışma, Journal of Yaşar University, 2013, 30(8), 5049-5063.

Anonim (2018). Şarköy hakkında. https://tekirdagsarkoy.com/hakkinda/ (Erişim Tarihi 17.12.2019).

Anonim. (2012). Şarköy Sofrası. Şarköy Belediye Yayınları, Tekirdağ.

Aslan, Z., Güneren, E. ve Çoban, G. (2014). Destinasyon Markalaşma Sürecinde Yöresel Mutfağın Rolü: Nevşehir Örneği, Journal of Tourism and Gastronomy Studies 2/4 (2014) 3-13.

Bertella, G. (2011). Knowledge in Food Tourism: The Case of Lofoten and Maremma Toscana, Current Issues in Tourism, 14 (4): 355-371.

Çakır, A. ve Çakır, G. (2012). Kırsal Kalkınmayı Sağlayıcı Bir Unsur Olarak Şarköy ve Çevresinde Kırsal Turizm Potansiyelinin Değerlendirilmesi, KMÜ Sosyal ve Ekonomik Araştırmalar Dergisi, 14 (22): 53-60.

Chang, R. C. Y., Kivela, J. ve Mak, A. H. N. (2010). Food preferences of Chinese tourists. Annals of Tourism Research, 37 (4), 989-1011.

Deneault, M. (2002). Acquiring a Taste for Cuisine Tourism; A Product Development Strategy, Canada.

DHA (2015). Şarköy'de Yaz Nüfusu 400 Bine Çıktı. https://www.haberler.com/sarkoyde-yaz-nufusu-400-bine-cikti-7521193-haberi/ (Erişim Tarihi 15.12.2019).

Getz, D. (2000). Explore Wine Tourism, Management, Development And Destinations, Cognizant Communication Corporation: New York.

Hewison (1987). The Heritage Industry Britain In A Climate Of Decline. London: Methuen.

Hjalager, A. M. ve Richards, G. (2002). Tourism and Gastronomy Routledge Advances in Tourism, 224-235.

lyer, P. (2000) The Global Soul, London: Bloomsbury.

Karasar, N. (2005). Bilimsel Araştırma Yöntemi, Ankara: Nobel Yayınları.

Karasar, N. (2011). Bilimsel Araştırma Yöntemi. Ankara: Nobel Yayınları.

Kesici, M. (2012). Kırsal Turizme Yönelik Olan Yöresel Talepte Yiyecek ve İçecek Kültürünün Rolü, KMÜ Sosyal ve Ekonomı k Araştırmalar Dergisi, 37.

Kılıçhan, R. (2015). Gastronomi Bilimine Yeni Bir Bakış, Cittaslow Gökçeada II. EkoGastronomi Kongresi Gökçeada, 13-14 Nisan 2015.

Kiper, T., Özyavuz, M. ve Korkut, A. (2011). Doğal Peyzaj Özelliklerinin Kırsal Turizm Gelişimine Etkisi: Tekirdağ İli Şarköy İlçesi Örneği, Tekirdağ Ziraat Fakültesi Dergisi Journal of Tekirdag Agricultural Faculty, 8 (3).

Kiracı M. A. (2006). Tekirdağ Ili Şarköy İlçesi Bağcılığının Mevcut Durumu, Üreticilerin Sorunlarının Çözümüne Illişkin Örgütlenme Olanaklarının Belirlenmesi. Trakya Üniversitesi, Fen Bilimleri Enstitüsü, Yüksek Lisans Tezi, 72s, Tekirdağ.

Küçükaltan D. ve Ultanır G. (2012). Trakya'da Kırsal Turizmin Uygulanabilirliği: Şarköy Örneği, KMÜ Sosyal ve Ekonomik Araştırmalar Dergisi 14 (22): 125-130. 
López-Guzmán, T. ve Sánchez-Cañizares, S. (2011). Gastronomy, Tourism and Destination Differentiation: A Case Study in Spain, Review of Economics \& Finance, 63-72.

McKrecher, B., Okumuş, F. ve Okumuş, B. (2008). Food Tourism as a Viable Market Segment: It's All How You Cook the Numbers. Journal of Travel\&Tourism Marketing. 2(2): 137-148.

Mil, B. (2007). Nitel Araştırma Tekniği Olarak Görüşme. İçinde A. Yüksel, B.Mil, Y. Bilim (Editör), Nitel Araştırma. Ankara: Detay Yayıncılık.

Mil, B. ve Denk, E. (2015). Erzurum Mutfağı Yöresel Ürünlerin Otel Restoran Menülerinde Kullanım Düzeyi: Palandöken Örneği, International Journal of Social and Economic Sciences 5 (2), 1-7.

Mitchell, R. ve Hall, C. M. (2006). Wine Tourism Research: The State of Play, Tourism Review International, 9 (4): 307-332.

Munsters, W. (1994). Cultuur X Toerisme: Louter Een Verstandshuwelijk?, Cultuurteorisme. Leuven: Grant, 1-44.

OECD (2014). Tourism and The Creative Economy. OECD Studies on Tourism, OECD Publishing.

Özyavuz, M. (2010). Doğal ve Kültürel Değerlerin Üç Boyutlu Sunum Teknikleri ile Görselleştirilmesi Şarköy Örneği, Şarköy Değerleri Sempozyumu, Şarköy, Tekirdağ.

Şen, N. ve Silahşör, Y. (2018). Gastronomi Turizmi Kapsamında Erzincan İli Yiyecek İçecek İşletmelerinde Sunulan Yöresel Yemekler Üzerine Bir Araştırma. Güncel Turizm Araştırmaları Dergisi, 2(Ek.1), 414-429.

Sünnetçioğlu, S., Can, A. ve Durlu-Özkaya, F. (2012). Yavaş Turizmde Coğrafi İşaretlemenin Önemi, 13. Ulusal Turizm Kongresi 6-9 Aralık 2012, Antalya, 953962.

Tikkanen, I. (2007). Maslow's Hierarchy and Food Tourist in Finland: Five Cases, British Food Journal, 109 (9): 721-734.

Trakya Kalkınma Ajansı (2013). Tekirdağ İlinde Doğa Turizmi Master Planı 2013 2023, http://bolge1.ormansu.gov.tr/1bolge/Files/tekirdag.pdf (Erişim Tarihi 23.12.2019).

Türk Patent (2020). Coğrafi İşaret ve Geleneksel Ürün Adı İstatistikleri. https://www.turkpatent.gov.tr/TURKPATENT/geographicalRegisteredList/ 10.01.2020.

TÜRSAB (t.y.). Gastronomi Turizmi Raporu. http://www.tursab.org.tr/dosya/12302/tursab-gastronomi-turizmi-raporu_12302_3531549.pdf (Erişim Tarihi 22.12.2019).

Yergaliyeva, A. (2011). Destinasyon Markalaşma Sürecinde Yerel Mutfağın Yeri (Uralsk Bölgesi'ndeki Restoranlar Üzerine Bir Araştırma). Yayınlanmamış Yüksek Lisans Tezi, Balıkesir Üniversitesi Sosyal Bilimler Enstitüsü, Balıkesir.

Yıldırım, A. ve Şimşek, H. (2008). Nitel Araştırma Yöntemleri. Ankara: Seçkin Yayınları.

Yüncü, H. R. (2009). Sürdürülebilir Turizm Açısından Gastronomi Turizmi ve Perşembe Yaylası, 10. Aybastı-Kabataş Kurultayı, Eskişehir. 


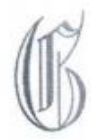

$(10)$
T.C.

ISTANBUL GELISTIM ÜNIVERSITESI

Etik Kurul Başkanlığı

\section{ETIK KURUL KARAR ÖRNEĞI}

TOPLANTI TARIHI : 23.09 .2020

TOPLANTI SAYISI : $2020-25$

KARAR NO: 2020-25-24: Uygulamalı Bilimler Yüksekokulu, Gastronomi Bölümü Dr. Öğr. Üyesi Özgür KIZILDEMIR ve Enver ȘIMȘEK'in, "Gastronomi Turizmi Kapsamında Yöresel Yemeklerin Restoranlarda Sunulması Üzerine Bir Araştırma: Şarköy Örneği" konulu çalışması hakkında yapacağı anket sorularının, etik kurallara uygun olup olmadığını tespit etmek üzere, İGÜ Etik Kurul Yönergesinin 12(1) maddesine göre değerlendirme yapmak üzere görevlendirilen ögretim elemanlarımın raporları incelenmiş olup, ilgili çalıșmada yer alan bilimsel araștırmanın etik kurallara uygun oldug̃una oy çokluğu ile karar verildi. 